\title{
Performance of Pilot-scale Vertical Flow Constructed Wetlands With and Without the Emergent Macrophyte Spartina alterniflora Treating Mariculture Effluent
}

\author{
Wilson Treger Zydowicz Sousa ${ }^{1^{*}}$, Clarice Maria Neves Panitz ${ }^{2}$ and Sidinei Magela \\ Thomaz $^{3}$ \\ ${ }^{1}$ Instituto de Tecnologia e Pesquisa; Universidade Tiradentes; 49032-490, Aracaju - SE - Brasil. ${ }^{2}$ Centro de \\ Ciências Biológicas; Universidade Federal de Santa Catarina; Florianópolis - SC - Brasil. ${ }^{3}$ Núcleo de Pesquisas \\ em Limnologia, Ictiologia e Aqüicultura; Universidade Estadual de Maringá; Maringá - PR - Brasil
}

\begin{abstract}
Vertical flow constructed wetlands, planted with and without Spartina alterniflora, were tested for the treatment of mariculture wastewater. Wetlands with and without the emergent macrophyte produced reductions of 89 and $71 \%$ for inorganic solids, 82 and $96 \%$ for organic solids, 51 and $63 \%$ for total nitrogen, 82 and $92 \%$ for ammoniacal nitrogen, 64 and 59\% for orthophosphate, and 81 and $89 \%$ for turbidity, respectively. Wetlands with S. alterniflora showed denitrification tendencies, while wetlands without S. alterniflora had higher oxygen levels leading to nitrification. The results suggest the fundamental role of oxygen controlling the purification processes as well as the potential of constructed wetlands to treat mariculture effluents.
\end{abstract}

Key words: artificial wetlands, dissolved oxygen, nitrification, denitrification, pollutant removal, mariculture effluent

\section{INTRODUCTION}

Interest in using natural and artificial wetlands to treat municipal, agricultural and industrial wastewaters has increased substantially since the 1980s. The main advantage of wetlands over the conventional treatment technologies is the low cost of implementation and management, since the processes of pollutant removal are based on naturally-occurring ecological processes. The main components of wetland systems are the substrate, the microbial community, and the vegetation, which together act in the treatment of wastewaters through the interaction of many abiotic (e.g. filtration, sedimentation, precipitation, adsorption) and biotic processes (e.g. organic matter mineralization, nutrient absorption, nitrification and denitrification). These purification processes are influenced by a complex set of factors, ranging from regional (e.g. temperature, photoperiod), to local (e.g. hydrology, substrate and vegetation type) and microscopic scales (e.g. microbial processes, molecular diffusion) (IWA, 2000; Stottmeister et al., 2003).

Owing to the complexity of factors governing the processes of wastewater purification, it has been challenging to understand and predict the effects of wetlands upon eutrophic effluents (Wiessner et

*Author for correspondence: wtzsousa@gmail.com 
al., 2005a, 2005b; Lymbery et al., 2006; Sindilariu et al., 2007; Borges et al., 2008). The wide flexibility in constructed wetlands design and operation adds to the challenge (IWA, 2000; Stottmeister et al., 2003). Recently, many studies have produced important information about basic factors affecting purification processes such as oxygen flow (Wu et al., 2001), redox potential (Wiessner et al., 2005a), sulfur cycle (Wiessner et al., 2005b), salinity (Lymbery et al., 2006), and vegetation dominance (Maine et al., 2007b). Beyond allowing an effective technological application for wetland systems, this knowledge can be fundamental in the area of conservation and management of natural wetlands (Sundareshwar et al., 2003).

Based on both economic and environmental demands for more sustainable production practices (e.g., Baccarin and Camargo, 2005; Ramos et al., 2009), the aquaculture community has constructed wetlands as a promising option to deal with its wastewaters, which have eutrophic characteristics. However, there is still a lack of knowledge to allow complete understanding and optimization of key processes such as organic mineralization, nitrification, denitrification, and phosphorus removal (Lin et al., 2005; Lymbery et al., 2006; Sindilariu et al., 2007). Studies about the treatment of marine (Sansanayuth et al., 1996) or brackish (Tilley et al., 2002) aquaculture wastewater by constructed wetlands are scarce. The aim of the present work was to evaluate, on an experimental scale, the performance of vertical flow constructed wetlands (VFWs) with free water column, with and without the emergent halophyte Spartina alterniflora, in treating effluent from marine shrimp postlarvae culture.

\section{MATERIAL AND METHODS}

\section{Culture of shrimp postlarvae}

The experiment was undertaken at the Marine Shrimp Laboratory (LCM-UFSC) (Lat. 27 35 'S; Long. 48 $26^{\prime} \mathrm{W}$ ), Florianópolis, Brazil, where postlarval (PL) Litopeneaus vannamei were produced at a commercial scale. The shrimps were reared in 12 circular culture tanks $\left(45 \mathrm{~m}^{3}\right.$ each), in greenhouses, with stocking densities of around $65 \mathrm{PL} \mathrm{L}^{-1}$ for about 30 days. The culture tanks were fully-aerated by pressurized air flowing out of perforated pipes placed on the tank bottom. Commercial powder diet $(40 \%$ protein) was added at $2 \mathrm{~h}$ intervals, at the rates of $50-150$ g per $10^{6} \mathrm{PL}$, according to the culture stage. The replenishment of water was nearly $20 \%$ daily. The tanks were filled with seawater, sometimes diluted with groundwater for culture convenience.

\section{Design and operation of the pilot VFWs}

The experimental units comprised eight VFWs made with synthetic fiber containers, measuring 73 x $73 \times 40 \mathrm{~cm}$ (length $\mathrm{x}$ width $\mathrm{x}$ height), filled with $12 \mathrm{~cm}$ of crushed oyster shells (diameter 5-20 mm, porosity 63\%) and $13 \mathrm{~cm}$ of beach sand (average diameter $0.5 \mathrm{~mm}$, effective diameter $0.2 \mathrm{~mm}$, uniformity coefficient 3.5, porosity 31\%) (Fig. 1).

Each wetland cell was equipped with an air-lift type of recirculation system (a mechanism commonly applied in aquaculture tanks and aquariums to promote the vertical circulation of the water) composed of a rail of bored pipes (diameter $2.5 \mathrm{~cm}$ ), laid on half of the container bottom (Fig. 1B), connected with a vertical pipe crossing the substrate and ending with a horizontal outlet pipe (Fig. 1). A fine hose attached to a tap supplied air from the air compressor of the shrimp culture into the vertical pipe. When the wetland cell was filled (with $110 \mathrm{~L}$ of effluent, maintaining a free-water column of 10-12 cm), the air injected in the vertical pipe induced water flow through the recirculation system from the bottom up to $5 \mathrm{~cm}$ above the surface, spilling water onto the wetland center by the outlet pipe. Controlled by the air faucet, the water flow rate was regulated to $0.3 \mathrm{~L}$ $\mathrm{min}^{-1}$ (hydraulic residence time of $6 \mathrm{~h}$ ). Four wetlands cells were planted with $18 \mathrm{~kg} \mathrm{FW}$ of Spartina alterniflora per $\mathrm{m}^{2}$ (VFW-A) and the remaining cells were left unplanted (VFW-B).

The wetland cells were placed outdoors, near the culture tanks. The effluent was pumped from the drainage channel of the culture tanks to a plastic reservoir of $1.2 \mathrm{~m}^{3}$ and then distributed by gravity to the wetland cells (Fig. 2). Each wetland was filled at a flow rate of c. $1 \mathrm{~L} \mathrm{~min}^{-1}$ until reach 110 $\mathrm{L}$, totalizing c. $2 \mathrm{~h}$ of filling until the activation of the recirculation system. The wastewater was left under treatment during one week and then the wetlands were drained at night and filled again in the next morning to treat a new effluent load. This pattern of operation was followed for four weeks (March - April 2002). 


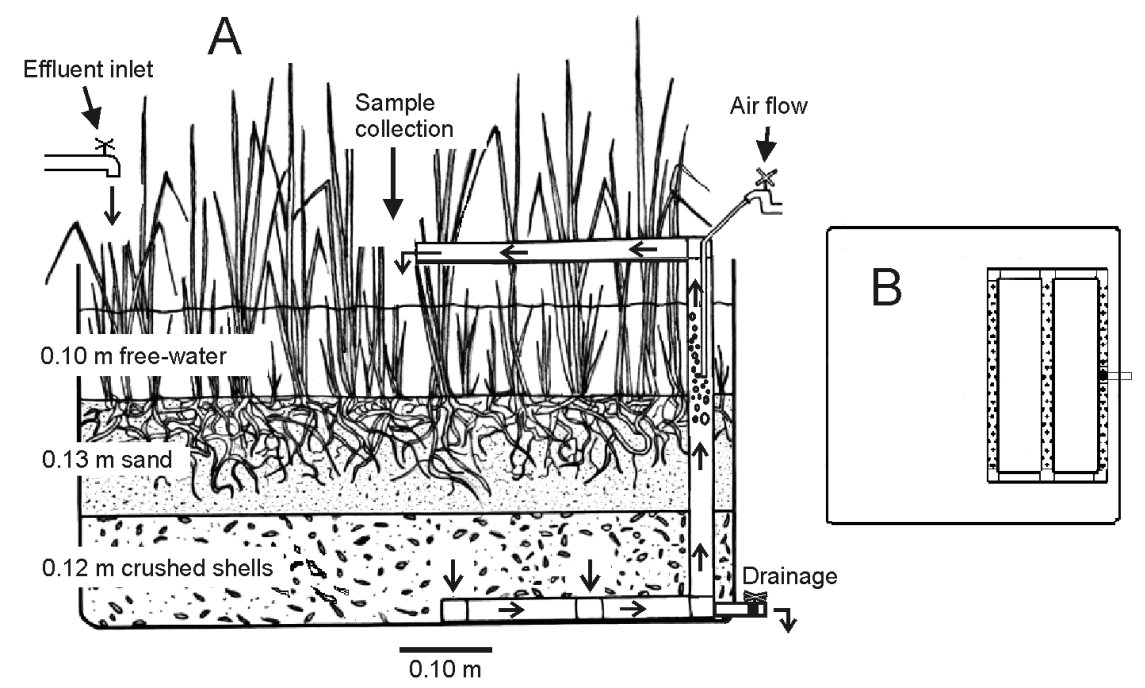

Figure 1 - (A) Outline of the VFW-A, and (B) the upper view of the rail of bored pipes of the recirculation system laid on the wetland bottom.

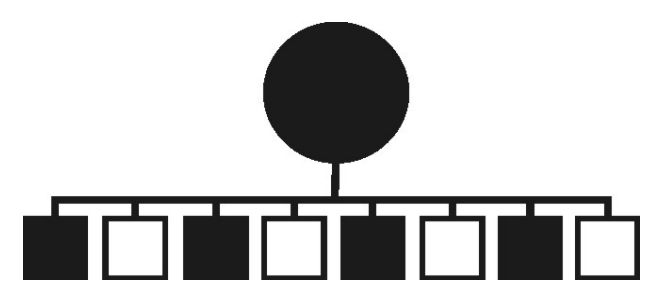

Figure 2 - Layout of the experiment facilities showing the effluent tank (black circle) and the VFW-A and VFW-B (black and blank quadrates, respectively).

\section{Sampling and analysis}

In April, during the supply of the fourth effluent load (fourth week of wetlands operation), at 7:00 $\mathrm{AM}$, a sample survey was initiated to evaluate the effect of the VFW-A and VFW-B upon water physico-chemical variables over $36 \mathrm{~h}$ of treatment. Water samples were collected for analyses from the gross effluent (time $0 \mathrm{~h}, \mathrm{n}=3$ ) and at the outlet pipe of each wetland at $6,12,24$ and $36 \mathrm{~h}$ after the effluent supply, but dissolved oxygen and $\mathrm{pH}$ were measured more frequently (e.g. at intervals of $3 \mathrm{~h}$ ). The water samples were analyzed for temperature, dissolved oxygen (DO), $\mathrm{pH}$, salinity, turbidity, inorganic (ISS) and organic suspended solids (OSS), total nitrogen (TN), ammoniacal nitrogen (ammoniacal-N), nitrite $\left(\mathrm{NO}_{2}-\mathrm{N}\right)$, nitrate $\left(\mathrm{NO}_{3}-\mathrm{N}\right)$ and orthophosphate.

Temperature, dissolved oxygen, $\mathrm{pH}$ and salinity were determined using a multi-parameter device (YSI, MP556 model). Turbidity was measured with a turbidimeter (HACH, XR model) expressed in nephelometric turbidity unit (NTU). Inorganic and organic suspended solids were determined gravimetrically (APHA, 1998). A known water volume was filtered through a $0.45 \mu \mathrm{m}$ glass-fiber Whatman $\mathrm{GF} / \mathrm{C}$ filter, previously dried $\left(110^{\circ} \mathrm{C}\right)$ and weighed. Later, filters were dried for $24 \mathrm{~h}$ at $60^{\circ} \mathrm{C}$. Total suspended solids were the difference between the filter's final and initial weights. Organic solids were determined by the loss of weight after combustion of the sample at $500^{\circ} \mathrm{C}$ for $12 \mathrm{~h}$. Total nitrogen was analyzed by the titrimetry (Kjeldahl method) (APHA, 1998). A spectrophotometer (Alfakit, AT-100PB model) was used for the analysis of ammoniacal nitrogen, determined by indophenol (Parsons et al., 1984), nitrite, by diazotation method, nitrate, by reduction in a $\mathrm{Cd}-\mathrm{Cu}$ column followed by diazotation, and orthophosphate, by the molybdenum blue method (Grasshoff et al., 1983).

Two-way ANOVA with repeated measures was applied to infer the effects of wetland type (VFWA and VFW-B) and time of treatment $(0,6,12,24$ and $36 \mathrm{~h}$ ) upon the water variables. The analysis 
was constrained to a significance level of 0.05 , using Statistica 7 software.

\section{RESULTS}

On the first day of sampling, the maximum radiation was $0.94 \mathrm{MJ}$ (at $1 \mathrm{PM}$ ), decreasing on the second day to $0.23 \mathrm{MJ}$ (at noon) due to cloudy conditions, while evaporation (Pichê) was $3.7 \mathrm{~mm}$ for both the days (data from INMET - EPAGRI SC). The average water temperature was $25.7{ }^{\circ} \mathrm{C}$ on the first day and decreased to $22.1{ }^{\circ} \mathrm{C}$ on the second.

The two-way ANOVA pointed to significant effects of effluent treatment (time effect) upon all the variables, with exception for inorganic solids (Table 1). VFW-A differed statistically from VFW-B in regard to dissolved oxygen, $\mathrm{pH}$, turbidity, nitrite, nitrate, orthophosphate and salinity. Interactions among the effects of time and wetlands were shown for oxygen, $\mathrm{pH}$, nitrite, nitrate and salinity.

Table 1 - Water physico-chemical variables (means $\pm \mathrm{SD})$ in the untreated effluent $(\mathrm{n}=3)$ and in the VFW-A and VFW-B ( $\mathrm{n}=16$ for each wetland type), with results from the two-way ANOVA $(p)$ upon the effects of time of treatment and wetland type.

\begin{tabular}{|c|c|c|c|c|c|c|}
\hline \multirow{2}{*}{ Variables } & \multirow{2}{*}{ Effluent } & \multirow{2}{*}{ VFW-A } & \multirow{2}{*}{ VFW-B } & \multicolumn{3}{|c|}{ ANOVA $(p)$} \\
\hline & & & & Time & Wetland & Interaction \\
\hline $\mathrm{DO}\left(\mathrm{mg} \mathrm{L}^{-1}\right) *$ & $6.5 \pm 0.0$ & $5.1 \pm 1.4$ & $6.4 \pm 1.3$ & $<0.001$ & $<0.001$ & $<0.001$ \\
\hline $\mathrm{pH} *$ & $8.2 \pm 0.0$ & $7.8 \pm 0.1$ & $8.3 \pm 0.1$ & $<0.001$ & $<0.001$ & $<0.001$ \\
\hline ISS $\left(\mathrm{mg} \mathrm{L}^{-1}\right)$ & $24 \pm 26$ & $14 \pm 10$ & $4 \pm 5$ & 0.185 & 0.112 & 0.763 \\
\hline OSS $\left(\mathrm{mg} \mathrm{L}^{-1}\right)$ & $19 \pm 8$ & $6 \pm 3$ & $2 \pm 2$ & $<0.001$ & 0.116 & 0.554 \\
\hline Turbidity (N.T.U.) & $7.7 \pm 0.4$ & $2.6 \pm 1.1$ & $1.5 \pm 0.9$ & $<0.001$ & 0.027 & 0.207 \\
\hline $\mathrm{NT}\left(\mathrm{mg} \mathrm{L}^{-1}\right)$ & $5.2 \pm 1.7$ & $2.1 \pm 1.1$ & $1.7 \pm 1.3$ & 0.007 & 0.112 & 0.480 \\
\hline Ammoniacal-N $\left(\mathrm{mg} \mathrm{L}^{-1}\right)$ & $2.36 \pm 0.03$ & $0.81 \pm 0.37$ & $0.49 \pm 0.40$ & $<0.001$ & 0.081 & 0.267 \\
\hline $\mathrm{NO}_{2}-\mathrm{N}\left(\mathrm{mg} \mathrm{L}^{-1}\right)$ & $0.07 \pm 0.01$ & $0.03 \pm 0.02$ & $0.56 \pm 0.15$ & $<0.001$ & 0.001 & $<0.001$ \\
\hline $\mathrm{NO}_{3}-\mathrm{N}\left(\mathrm{mg} \mathrm{L}^{-1}\right)$ & $0.94 \pm 0.04$ & $0.55 \pm 0.19$ & $1.03 \pm 0.67$ & 0.006 & 0.001 & 0.027 \\
\hline Orthophosphate $\left(\mathrm{mg} \mathrm{L}^{-1}\right)$ & $1.57 \pm 0.11$ & $0.76 \pm 0.18$ & $1.03 \pm 0.28$ & $<0.001$ & 0.010 & 0.289 \\
\hline Salinity $\left(\mathrm{g} \mathrm{L}^{-1}\right)$ & $20.0 \pm 0.1$ & $21.3 \pm 0.1$ & $21.5 \pm 0.4$ & $<0.001$ & 0.025 & $<0.001$ \\
\hline
\end{tabular}

$* \mathrm{n}=44$ for VFW-A and VFW-B; these variables ( $\mathrm{DO}$ and $\mathrm{pH}$ ) were measured more frequently (see section Sampling and analysis and Figure 3) totalizing 44 samples for each wetland type, collected between $3 \mathrm{~h}$ and $36 \mathrm{~h}$ of effluent treatment (11 times of effluent treatment $x 4$ replicates). All other variables were measured with 6, 12, 24 and $36 \mathrm{~h}$ of effluent treatment, totalizing 16 samples for each wetland type (4 times of effluent treatment $\mathrm{x} 4$ replicates).

VFW-B sustained higher values of oxygen and $\mathrm{pH}$ than VFW-A (Fig. 3A-B). The lowest oxygen levels in VFW-A $\left(1.7 \pm 0.7 \mathrm{mg} \mathrm{L}^{-1}\right)$ and VFW-B $\left(3.8 \pm 0.5 \mathrm{mg} \mathrm{L}^{-1}\right)$ were measured at $3 \mathrm{~h}$ of treatment (favoured by the water stagnancy before the full supply of effluent and activation of the recirculation). After that oxygen gradually increased, especially in VFW-B. The mean oxygen concentration on the first day was $4.2 \pm 1.4 \mathrm{mg} \mathrm{L}^{-1}$ for VFW-A and $5.4 \pm 0.9 \mathrm{mg} \mathrm{L}^{-1}$ for VFW-B, rising in the second day to $5.9 \pm 0.7$ and $7.3 \pm 0.8$ $\mathrm{mg} \mathrm{L}^{-1}$, respectively. The $\mathrm{pH}$ levels oscillated, tending to increase in daylight and decrease at night (Fig. 3B, note that $0 \mathrm{~h}$ corresponded to 7:00 AM, see methods). Nevertheless, the wetlands were well buffered and variations were not large.
Minimum and maximum $\mathrm{pH}$ values recorded in a wetland cell were $7.5-8.0$ for VFW-A and $8.0-$ 8.6 for VFW-B.

The concentration of inorganic solids in the gross effluent was reduced in $89 \%$ by VFW-A and $71 \%$ by VFW-B after $36 \mathrm{~h}$ of treatment (Fig. 3C), but these differences were not statistically significant (Table 1) due to a large data variance, mainly for VFW-A. Organic solids were reduced by $50 \%$ by VFW-A and $80 \%$ by VFW-B after $6 \mathrm{~h}$ of treatment, and reached reductions of 82 and $96 \%$, respectively after $36 \mathrm{~h}$ (Fig. 3C). Turbidity was reduced by 52 and $68 \%$ after $6 \mathrm{~h}$, and 81 and $89 \%$ after $36 \mathrm{~h}$ by VFW-A and VFW-B, respectively (Fig. 3D). 

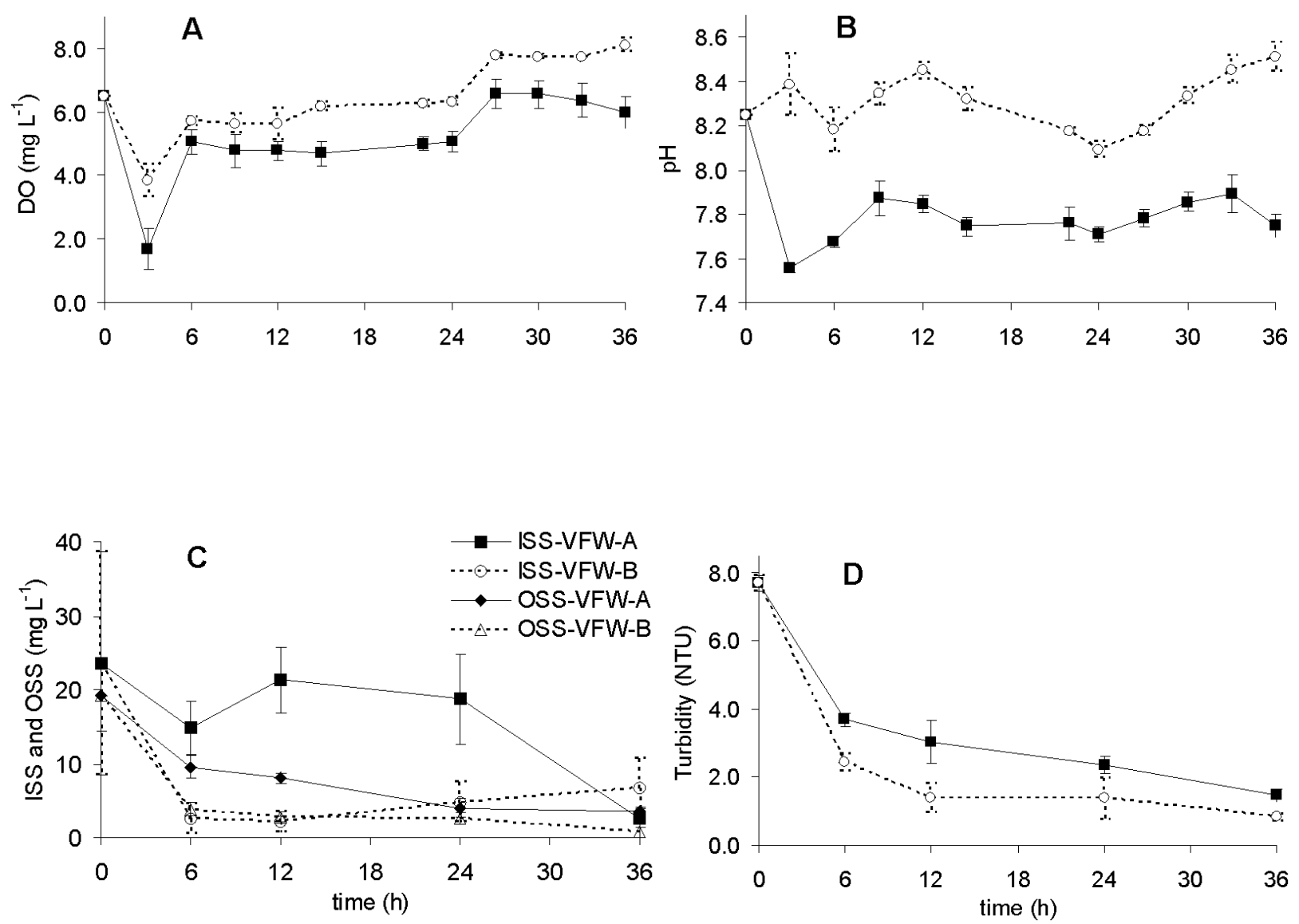

Figure 3 - Effect of VFW-A (-) and VFW-B (- - ) throughout $36 \mathrm{~h}$ of mariculture effluent treatment upon: (A) total nitrogen, (B) ammoniacal nitrogen, (C) nitrite, (D) nitrate, (E) orthophosphate and (F) salinity $($ mean $\pm \mathrm{SE})$.

Total nitrogen showed reductions of $66 \%$ in VFW$A$ and $76 \%$ in VFW-B after $6 \mathrm{~h}$, but these efficiencies decreased to 51 and $63 \%$, respectively, with $36 \mathrm{~h}$ (Fig. 4A). Ammoniacal nitrogen was reduced $52 \%$ by VFW-A and 59\% by VFW-B in 6 $\mathrm{h}$, reaching 82 and $92 \%$, respectively, after $36 \mathrm{~h}$ (Fig. 4B). Nitrite was gradually removed by VFWA until stabilize to $75 \%$ reduction at $24 \mathrm{~h}$ of treatment (Fig. 4C). In the VFW-B, nitrite had a drastic increase of $819 \%$ at $6 \mathrm{~h}$, staying in the range of $0.42-0.75 \mathrm{mg} \mathrm{L}^{-1}$ between 6 and $24 \mathrm{~h}$ and then a smooth decline from 24 to $36 \mathrm{~h}$, which represented an increase of $495 \%$ in relation to the untreated effluent. Nitrate in the VFW-A declined $55 \%$ at $12 \mathrm{~h}$, but this reduction decreased to $35 \%$ at $36 \mathrm{~h}$ (Fig. 4D). In the VFW-B, nitrate tended to increase until $24 \mathrm{~h}$, reaching $106 \%$ higher than in the gross effluent, but at $36 \mathrm{~h}$, it was reduced $42 \%$ in relation to the gross effluent.

Orthophosphate was reduced by $50 \%$ in VFW-A and 26\% in VFW-B after $6 \mathrm{~h}$, reaching 64 and $59 \%$, respectively after $36 \mathrm{~h}$ (Fig. 4E). The salinity increased $7 \%$ in VFW-A and $11 \%$ in VFW-B after $6 \mathrm{~h}$ and then stabilized with a $6 \%$ increase until 36 $\mathrm{h}$ in both the wetlands (Fig. 4F). 

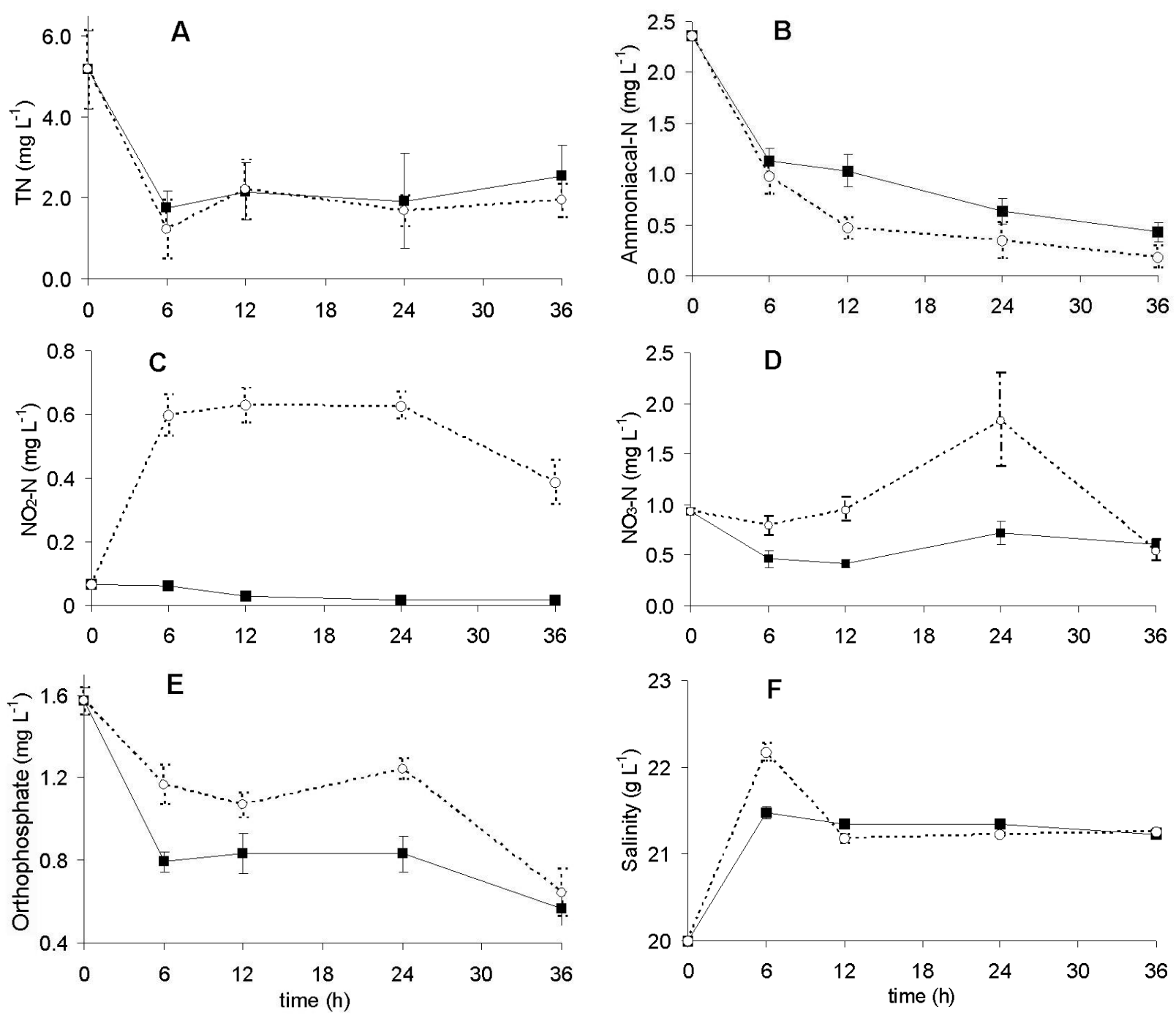

Figure 4 - Effect of VFW-A (-) and VFW-B (- - -) throughout $36 \mathrm{~h}$ of mariculture effluent treatment upon: (A) total nitrogen, (B) ammoniacal nitrogen, (C) nitrite, (D) nitrate, (E) orthophosphate and (F) salinity (mean \pm SE).

\section{DISCUSSION}

Emergent macrophytes such as S. alterniflora are able to affect the biogeochemical cycles in the interstitial water through the release of oxygen from their roots (Howes et al., 1981; Colmer, 2003). However, studies have shown that the oxygen provided by the plants alone could not meet the demand of purification processes such as organic mineralization and nitrification in subsurface flow constructed wetlands applied to treat eutrophic wastewaters, suggesting that the main source of oxygen was from atmospheric diffusion (Bowmer, 1987; Wu et al., 2001). In the present study, wetlands without emergent macrophytes (VFW-B) showed the highest levels of oxygen. This result was likely promoted by a larger gas diffusion due to the free wind action on the atmosphere-water interface, as well as by elevated algal photosynthetic activity (filamentous algae and the macroalgae Enteromorpha sp. flourished in VFW-B) propitiated by the high incidence of solar radiation over the water column in VFW-B, while VFW-A units were sheltered by S. alterniflora.

The nitrogen removal by the VFWs (> 51\%) could be attributed to several processes such as filtration of organic particles, biological assimilation, 
denitrification and $\mathrm{NH}_{3}$ volatilization (IWA, 2000). The present results are comparable to the ones supported by Sansanayuth et al. (1996), which showed nitrogen reductions of $48-61 \%$ treating the effluent from marine shrimp culture containing nitrogen concentrations $(4.4-4.8 \mathrm{mg}$ $\mathrm{L}^{-1}$ ) close to those applied in the present study.

The VFW-A and VFW-B were fairly efficient in treating the ammoniacal nitrogen. In addition to biotic assimilation, the better performance of VFW-B (even though without statistical significance, $p=0.08$ ) was possibly promoted by its high levels of oxygen and $\mathrm{pH}$ (often above 8.0), favoring nitrification and $\mathrm{NH}_{3}$ volatilization, respectively (IWA, 2000). Studies utilizing a natural mangrove wetland (Gautier et al., 2001) and a free water surface flow constructed wetland (Tilley et al., 2002) to treat the brackish effluent from shrimp culture recorded ammoniacal nitrogen increases likely due to dissolved oxygen limitations to effectively sustain sequential processes of mineralization and nitrification (Herbert, 1999; Chen et al., 2006). As confirmed in this study, the artificial wetlands with subsurface flow usually reached high ammoniacal nitrogen removal from aquaculture effluents (Schultz et al., 2003; Lin et al., 2005; Sindilariu et al., 2007).

Heterotrophic bacteria have a competitive advantage over nitrifying bacteria, hence the available oxygen is preferentially utilized for organic mater mineralization instead of ammoniacal nitrogen oxidation (Herbert, 1999; Chen et al., 2006). For the entire oxidation of ammoniacal nitrogen, which occurs via the transformation to nitrite, principally by the action of Nitrosomonas, then to nitrate by Nitrobacter, sufficient oxygen is also necessary. Nitrobacter are more sensitive to oxygen shortage than Nitrosomonas, which favors the accumulation of nitrite in biofilters (Chen et al., 2006). Formation of nitrite in the VFW-B had already occurred at the sixth hours of treatment, while nitrate only increased after $24 \mathrm{~h}$. It was probable that on the first day the dissolved oxygen was just sufficient to permit the simultaneous actions of heterotrophic bacteria and Nitrosomonas. On the second day, with the labile organic compounds already mineralized and ammoniacal nitrogen almost depleted, there was oxygen availability to allow the action of Nitrobacter. In another way, the lower oxygen levels in the VFW-A appeared to favor the denitrifying processes, though the small increase of nitrate at $24 \mathrm{~h}$ showed the existence of some nitrification activity in these wetlands.

Sequential processes of nitrification and denitrification, which occurs by the passage of the wastewater through oxidative and reductive zones, resulting in nitrogen volatilization, are one of the main purification phenomena in wetlands (IWA, 2000). However, in wetlands applied for the aquaculture, these processes have not been easily predicted and optimized (Schulz et al., 2003; Lin et al., 2005; Sindilariu et al., 2007). For example, Lin et al. (2005) related the storage of nitrate in a constructed wetland linked with a shrimp culture to a high hydraulic loading rate and scarcity of organic carbon, but it also could be due to high oxygen concentrations preventing denitrifying activities. The present results suggested that the nitrification and denitrification processes could be optimized by the control of oxi-reducing conditions, which was affected by oxygen availability.

As an ecological system, artificial wetlands experience auto-organizing processes, such as ecological succession, in which organisms better adapted to the prevailing environmental conditions (e.g. in terms of resource allocation) naturally develop and dominate the habitat (IWA, 2000; Tilley et al., 2002; Maine et al., 2007b). The VFW-B demonstrated this ability with the development of filamentous algae and macroalgae (Enteromorpha sp.) in the water column. Several studies have shown the suitability of submersed macroalgae for treating the mariculture wastewaters (Hernandez et al., 2002; MartinezAragón et al., 2002; Neori et al., 2004; Hayashi et al., 2008; Marinho-Soriano et al., 2009). Besides assimilating nutrients, through photosynthesis, macroalgae can elevate oxygen and $\mathrm{pH}$ levels (Porrello et al., 2003; Msuya et al., 2006) and propitiate processes of mineralization and nitrification.

The oyster shells employed as wetland substrate are basically made of $\mathrm{CaCO}_{3}$. The phosphorus cycle in wetlands may be influenced by the coprecipitation of phosphate with $\mathrm{CaCO}_{3}$ in cases of $\mathrm{pH}$ increase, as well as by dissolution of phosphate when $\mathrm{pH}$ decreases (Wetzel, 1983; Dierberg et al., 2002; Maine et al., 2007a). The courses of $\mathrm{pH}$ and orthophosphate levels throughout the treatment in the VFW-B (see Figs. $3 \mathrm{~A}$ and 4E) were likely an evidence of these phenomena. Similar to Sansanayuth et al. (1996), this study also found higher orthophosphate 
removals by wetlands with macrophytes, despite the lower $\mathrm{pH}$ values. Besides the assimilation by $S$. alterniflora, anaerobic heterotrophic bacteria (e.g. denitrifying bacteria) can play an important hole in the cycle of phosphorus (Barak et al., 2003; Sundareshwar et al., 2003) and also could have absorbed substantial amounts of orthophosphate in the VFW-A.

In concern to the salinity increases observed in the wetlands, evaporation processes can lead to salt storage especially in wetlands used for the treatment of saline wastewaters (e.g. Sansannayuth et al., 1996) and washing salts with low-salinity water is the most obvious technique to mitigate the problem.

\section{CONCLUSIONS}

The pilot wetlands attained good levels of pollutant removal. Wetlands with $S$. alterniflora reached larger orthophosphate removal and showed denitrification tendencies, while wetlands without emergent macrophytes had higher levels of oxygen and $\mathrm{pH}$, favoring mineralization of organic matter, nitrification and $\mathrm{NH}_{3}$ volatilization.

Results demonstrated the potential of constructed wetlands to treat the mariculture effluents and highlighted the role of oxygen as a main driver regulating the processes of pollutant removal, especially those related to oxidation and reduction phenomena.

\section{ACKNOWLEDGEMENTS}

The authors thank the Marine Shrimp Laboratory of the Universidade Federal de Santa Catarina for allowing the development of this study, Dr. Kevin J. Murphy, Dr. William Severi and Dr. Carolina V. Minte-Vera for the manuscript revision, and CAPES / CNPQ for financial support.

\section{REFERENCES}

APHA (1998), Standard Methods for the Examination of Water and Wastewater. American Public Health Association, New York, 1268p.

Baccarin, A. E. and Camargo, A. F. M. (2005), Characterization and evaluation of the impact of feed management on the effluents of Nile tilapia
(Oreochromis niloticus) Culture. Braz. Arch. Biol. Technol., 48, 81-90.

Barak, Y.; Cytryn, E.; Gelfand, I.; Krom, M. and van Rijn, J. (2003), Phosphorus removal in a marine prototype, recirculating aquaculture system. Aquac., 220, 313-326.

Borges, A. K. P.; Tauk-Tornisielo, S. M.; Domingos, R. N. and Angelis, D. F. (2008), Performance of the constructed wetland system for the treatment of water from the Corumbataí river. Braz. Arch. Biol. Technol., 51, 1279-1286.

Bowmer, K. H. (1987), Nutrient removal from effluents by an artificial wetland: influence of rhizosphere aeration and preferential flow studied using bromide and dye tracers. Water Res., 21, 591 - 599.

Chen, S.; Ling, J. and Blancheton, J. (2006), Nitrification kinetics of biofilm as affected by water quality factors. Aquac. Eng., 34, 179-197.

Colmer, T. D. (2003), Long-distance transport of gases in plants: a perspective on internal aeration and radial oxygen loss from roots. Plant Cell Environ., 26, 1736.

Dierberg, F. E.; DeBusk, T. A. and Jackson, S. D. (2002), Submerged aquatic vegetation-based treatment wetlands for removing phosphorus from agricultural runoff: response to hydraulic and nutrient loading. Water Res., 36, 1409-1422.

Gautier, D.; Amador, J. and Newmark, F. (2001), The use of mangrove wetland as a biofilter to treat shrimp pond effluents: preliminary results of an experiment on the Caribbean coast of Colombia. Aquac. Res., 32, 787-799.

Grasshoff, K.; Erhardt, M. and Kremling, K. (1983), Methods of seawater analysis, 2nd ed., Willey-VCH, Weinheim.

Hayashi, L.; Yokoya, N. S.; Ostini, S.; Pereira, R. T. L.; Braga, E. S. and Oliveira, E. C. (2008), Nutrients removed by Kappaphycus alvarezii (Rhodophyta, Solieriaceae) in integrated cultivation with fishes in re-circulating water. Aquac., 277, 185-191.

Herbert, R. A. (1999), Nitrogen cycling in coastal marine ecosystems. FEMS Microbiol. Rev., 23, 563590.

Hernandez, I.; Martinez-Aragón, J. F.; Tovar, A.; Pérez-Lloréns, J. L. and Vergara, J. J. (2002). Biofiltering efficiency in removal of dissolved nutrients by three species of estuarine macroalgae cultivated with sea bass (Dicentrarchus labrax) waste waters 2. Ammonium. J. Appl. Phycol., 14, 375-384.

Howes, B. L.; Howarth, R. W.; Teal, J. M. and Valiela, I. (1981), Oxidation-reduction potencials in a salt marsh: Spatial patterns and interactions with primary production. Limnol. Oceanogr., 26, 350-360.

International Water Association, 2000. Constructed Wetlands For Pollution Control: Processes, Performance, Design and Operation. Scientific and Technical Report $\mathrm{N}^{\mathrm{o}}$ 8. IWA Publishing, London, $156 \mathrm{p}$. 
Lin, Y.; Jing, S.; Lee, D.; Chang, Y.; Chen, Y. and Shih, K. (2005), Performance of a constructed wetland treating intensive shrimp aquaculture wastewater under high hydraulic loading rate. Environ. Pollut., 134, 411-421.

Lymbery, A. J.; Doupé, R. G.; Bennett, T. and Starcevich, M. R. (2006), Efficacy of a subsurfaceflow wetland using the estuarine sedge Juncus kraussii to treat effluent from inland saline aquaculture. Aquac. Eng., 34, 1-7.

Maine, M. A. ; Maine, M. A.; Suñe, N. ; Hadad, H. and Sánchez, G. (2007a). Temporal and spatial variation of phosphate distribution in the sediment of a free water surface constructed wetland. Sci. Total Environ., 380, 75-83.

Maine, M. A.; Suñe, N.; Hadad, H.; Sánchez, G. and Bonetto, C. (2007b), Removal efficiency of a constructed wetland for wastewater treatment according to vegetation dominance. Chemosphere, 68, 1105-1113.

Marinho-Soriano, E.; Nunes, S. O.; Carneiro, M. A. A. and Pereira, D. C. (2009), Nutrients' removal from aquaculture wastewater using the macroalgae Gracilaria birdiae. Biomass Bioenerg., 33, 327-331.

Martinez-Aragón, J. F.; Hernandez, I.; Pérez-Lloréns, J. L.; Vázquez R. and Vergara, J. J. (2002). Biofiltering efficiencies for dissolved inorganic phosphorus in three species of estuarine macroalgae cultivated with sea bass (Dicentrarchus labrax) waste waters. J. Appl. Phycol., 14, 375-384.

Msuya, F. E: Kyewalyanga, M. S and Salum, D. (2006), The performance of the seaweed Ulva reticulata as a biofilter in a low-tech, low-cost, gravity generated water flow regime in Zanzibar, Tanzania. Aquac., 254, 284-292.

Neori, A.; Chopin, T.; Troell, M.; Buschmann, A. H.; Kraemer, G. P.; Halling, C.; Shpigel, M. and Yarish, C. (2004), Integrated aquaculture: rationale, evolution and state of the art emphasizing seaweed biofiltration in modern mariculture. Aquac., 231, 361-391.

Parsons, T. R.; Maita, Y. and Lalli, C. M. (1984), A manual of chemical and biological methods for seawater analysis. Pergamon Press, Oxford, 173p.

Porrello, S.; Lenzi, M.; Persia, E.; Tomassetti, P. and Finoia., M. G. (2003), Reduction of aquaculture wastewater eutrophication by phytotreatment ponds system I. Dissolved and particulate nitrogen and phosphorus. Aquac., 219, 515-529.
Ramos, R.; Vinatea, L.; Seiffert, W.; Beltrame, E.; Silva, J. S. and Costa, R. H. R. (2009), Treatment of shrimp effluent by sedimentation and oyster filtration using Crassostrea gigas and C. rhizophorae. Braz. Arch. Biol. Technol., 52, 775-783.

Sansanayuth, P.; Phadungchep, A.; Ngammontha, S.; Ngdngam, S.; Sukasem, P.; Hoshino, H. and Ttabucanon, M. S. (1996), Shrimp pond effluent: pollution problems and treatment by constructed wetlands. Water Sci. Technol., 34, 93-98.

Schulz, C.; Gelbrecht, J. and Rennert, B. (2003), Treatment of rainbow trout farm effluents in constructed wetland with emergent plants and subsurface horizontal water flow. Aquac., 217, 207221.

Sindilariu, P.; Schulz, C. and Reiter, R. (2007), Treatment of flow-through trout aquaculture effluents in a constructed wetland. Aquac., 270, 92-104.

Stottmeister, U.; Wießner, A.; Kuschk, P.; Kappelmeyer, U.; Kästner, M.; Bederski, O.; Müller, R. A. and Moormann, H. (2003), Effects of plants and microorganisms in constructed wetlands for wastewater treatment. Biotechnol. Adv., 22, 93-117.

Sundareshwar, P. V.; Morris, J. T.; Koepfler, E. K. and Fornwalt, B. (2003), Phosphorus limitation of coastal ecosystem processes. Sci., 299, 263-265.

Tilley, D. R.; Badrinarayanan, H.; Rosati, R. and Son, J. (2002), Constructed wetlands as recirculation filters in large-scale shrimp aquaculture. Aquac. Eng., 26, 81-109.

Wetzel, R. G. (1983), Limnology. $2^{\text {nd }}$ Ed. Saunders College Publishing. Florida, 767p.

Wiessner, A; Kappelmeyer, U.; Kuschk, P. and Kästner, M. (2005a). Influence of the redox condition dynamics on the removal efficiency of a laboratoryscale constructed wetland. Water Res., 39, 248-256.

Wiessner, A; Kappelmeyer, U.; Kuschk, P. and Kästner, M. (2005b), Sulphate reduction and the removal of carbon and ammonia in a laboratory-scale constructed wetland. Water Res., 39, 4643-4650.

Wu, M.; Franz, E. H. and Chen, S. (2001), Oxygen fluxes and ammonia removal efficiencies in constructed treatment wetlands. Water Environ. Res., 73, 661-666. 